\title{
Pengembangan Kegiatan Ekstrakurikuler Bahasa Arab di Pondok Pesantren
}

\author{
Ni'mah Ziyadatul Khusnah, Kholisin, Ahmad Munjin Nasih \\ Universitas Negeri Malang \\ Corresponding author: nimahziyadah@gmail.com
}

\begin{abstract}
This study discusses the development of extracurricular activities in Arabic at Nurul Jadid Islamic Boarding School, Paiton-Probolinggo, which includes: 1) Types of activities, 2) Planning activities, 3) Implementation of activities, and 4) Evaluating activities. This study uses a qualitative descriptive method with a case study approach. The qualitative data in this study included extracurricular activities in Arabic. The data sources of this research are the core management and students in the LPBA. The instrument is the researcher himself (human instrument). Data collection was obtained through the results of distributing questionnaires, interviews, observation, and documentation. The results showed a number of things, namely (1) twelve extracurricular activities attended by students at ula and wushta levels with the hope that students often get used to listening to hiwar or Arabic conversations from native Arabs, and can apply them in daily conversations. day (2) Planning activities consist of student organizations, curriculum, schedule arrangements, activity themes, and regulations, (3) This activity is carried out every night after teaching and learning activities (KBM) and Friday from morning to evening, and (4) Evaluation of this activity is carried out once a month with the aim of finding solutions to problems experienced by students.
\end{abstract}

Penelitian ini membahas tentang pengembangan kegiatan ekstrakurikuler bahasa Arab di Pondok Pesantren Nurul Jadid, Paiton-Probolinggo, yang meliputi: 1) Jenis kegiatan, 2) Perencanaan kegiatan, 3) Pelaksanaan kegiatan, dan 4) Evaluasi kegiatan. Penelitian ini menggunakan metode deskriptif kualitatif 
dengan pendekatan studi kasus. Data kualitatif dalam penelitian ini meliputi kegiatan-kegiatan ekstrakurikuler bahasa Arab. Sumber data penelitian ini adalah pengurus inti dan peserta didik di LPBA. Instrumennya adalah peneliti sendiri (human instrument). Pengumpulan data diperoleh melalui hasil penyebaran angket, wawancara, observasi, dan dokumentasi. Hasil penelitian menunjukkan beberapa hal, yaitu (1) kegiatan ekstrakurikuler yang diikuti oleh peserta didik tingkatan ula dan wushta sebanyak dua belas kegiatan dengan harapan agar peserta didik sering membiasakan mendengarkan hiwar atau percakapan bahasa Arab dari orang Arab asli, serta dapat menerapkannya dalam percakapan sehari-hari (2) Perencanaan kegiatan terdiri dari organisasi peserta didik, kurikulum, susunan jadwal, tema kegiatan, dan peraturan tata tertib, (3) Kegiatan ini dilaksanakan setiap malam hari setelah kegiatan belajar mengajar (KBM) dan hari Jum'at mulai pagi sampai malam. dan (4) Evaluasi kegiatan ini dilaksanakan dalam satu bulan sekali dengan tujuan untuk menemukan solusi dalam masalah yang dialami oleh peserta didik.

Keywords: Kegiatan ekstrakutikuler; Bahasa Arab; Lembaga Pengembangan Bahasa Asing.

\section{Pendahuluan}

Bahasa merupakan satu wujud yang tidak bisa dipisahkan dari kehidupan manusia, sehingga dapat dikatakan bahwa bahasa itu adalah milik manusia yang telah menyatu dengan pemiliknya. Sebagai salah satu milik manusia, bahasa selalu muncul dalam segala aspek dan kegiatan manusia. Tidak ada satu pun kegiatan manusia yang tidak disertai dengan kehadiran bahasa.

Perkembangan bahasa khususnya bahasa Arab di Indonesia sendiri lebih cenderung berorientasi pada kalangan pondok pesantren. Seperti pondok pesantren Nurul Jadid yang menerapkan sistem bahasa Arab menjadi bahasa kedua setelah bahasa Indonesia untuk berkomunikasi antar santri dalam kehidupan sehari-hari. Pembelajaran bahasa Arab di pondok pesantren Nurul Jadid merupakan kegiatan yang hampir semua santri mengikutinya. Materi yang disajikan 
dalam kegiatan bahasa Arab antara lain, ilmu nahwu, ilmu sharaf, ilmu balaghah, dan kosakata bahasa Arab. Salah satunya pembelajaran ini dilaksanakan di lembaga pengembangan bahasa Asing (LPBA) Nurul Jadid yang di dalamnya terdapat kegiatan kebahasaan yang disebut dengan kegiatan ekstrakurikuler bahasa Arab. Kegiatan tersebut dilaksanakan sebagai salah satu cara agar peserta didik lebih mudah menguasai dan meningkatkan kemampuan bahasa Arabnya.

Kegiatan ekstrakurikuler merupakan salah satu program atau kegiatan yang terbilang efektif dalam meningkatkan skill atau kemampuan kebahasaan dan menerapkan berbicara bahasa Arab setiap hari dengan bentuk kewajiban bagi peserta didik, serta mengikuti berbagai macam kegiatan berbahasa Arab dengan peraturan maupun tata tertib dalam setiap kegiatannya. Pelaksanaan kegiatan berbahasa Arab selalu didampingi oleh pengurus dalam bentuk pengawasan maupun komunikasi secara langsung terhadap individu maupun kelompok sehingga proses pembelajaran menjadi lebih aktif.

Hasil observasi, penyebaran angket, dan wawancara kepada pengurus dan peserta didik di lembaga pengembangan bahasa Asing (LPBA), diperoleh hasil bahwa kegiatan ini dilaksanakan di depan kamar atau asrama setiap hari mulai pukul 21.00-23.00, kecuali di hari Jumat dimulai dari pagi hingga malam, yang diikuti oleh peserta didik tingkatan ula dan tingkatan wustha. Kegiatan tersebut menjadi sarana dalam meningkatkan pengetahuan dan pengembangan bakat maupun minat peserta didik dalam menguasai bahasa asing khususnya bahasa Arab.

Dari pemaparan di atas, peneliti tertarik untuk mengangkat judul "pola pengembangan kegiatan ekstrakurikuler bahasa arab di lembaga pengembangan bahasa asing (LPBA) Pondok Pesantren Nurul Jadid Paiton Probolinggo" ini karena terdapat sesuatu yang istimewa dari lembaga tersebut yaitu, sistem 
pembelajarannya secara study club, yang bertujuan untuk melatih skill peserta didik agar tidak monoton maka kegiatannya diisi dengan permainan. Untuk kelebihannya peserta didik LPBA sering mendapatkan penghargaan dari lomba-lomba yang diikuti oleh peserta didik yang dilaksanakan di dalam maupun di luar pondok pesantren, diantaranya pada maharah kalam di bidang lomba debat selama empat tahun berturutturut. Selain itu, tidak cukup hanya dengan hasil prestasi yang telah dicapai untuk mengukur kemampuan peserta didik namun bentuk kreatifitas peserta didik dalam berbahasa Arab juga mengalami perkembangan yang diperoleh dari kesehariannya dan partisipasi dalam mengikuti kegiatan.

Penelitian ini menggunakan metode deskriptif kualitatif dengan pendekatan studi kasus. Peneliti dapat memparkan pola pengembangan kegiatan ekstrakurikuler bahasa Arab di LPBA Pondok Pesantren Nurul Jadid Probolinggo mulai dari perencanaan sampai dengan evaluasi kegiatan ekstrakurikuler bahasa Arab. Data kualitatif dalam penelitian ini diperoleh melalui jenis, perencanaan, pelaksanaan dan evaluasi, meliputi kegiatan-kegiatan ekstrakurikuler bahasa Arab yang dilaksanakan di lembaga pengembangan bahasa Asing Nurul Jadid. Data tersebut diperoleh melalui hasil penyebaran angket, wawancara, lembar observasi, dan dokumentasi. Sedangkan sumber data dalam penelitian ini adalah pengurus inti dan peserta didik di LPBA Nurul Jadid. Yang dimaksud pengurus inti adalah pengurus yang membimbing dan mengontrol semua kegiatan di lembaga tersebut.

Instrumen pokok dalam penelitian ini adalah peneliti sendiri, sedangkan instrumen pendukung yang digunakan peneliti adalah lembar angket, pedoman wawancara, dan pedoman observasi. Setelah itu dilakukan pengumpulan data yang merupakan salah satu rangkaian penting dalam melaksanakan penelitian. Melalui pengumpulan data, akan 
diperoleh suatu informasi atau fenomena penting, sahih, dan terpercaya, sehingga temuan yang dihasikan oleh suatu penelitian secara ilmiah dapat dipertanggungjawabkan. ${ }^{1}$ Pengumpulan data dalam penelitian ini berupa penyebaran angket kepada peserta didik dan pengurus atau ustadzaat, wawancara yang dilakukan peneliti terhadap narasumber yaitu pengurus inti, observasi dilakukan oleh peneliti terhadap berlangsungnya kegiatan ekstrakutikuler, dan dokumentasi. Lalu, peneliti menganalisis data dengan cara megklasifikasi data, mengemukakan data, menyajikan dan menjelaskan, dan menyimpulkan data.

\section{Jenis Kegiatan}

Kegiatan ekstrakurikuler Bahasa Arab di laksanakan oleh Lembaga Bahasa Arab (LBA) yang merupakan salah satu sayap lembaga bahasa asing yang ada di Pondok Pesantren Nurul Jadid. LBA tergabung bersama Lembaga Bahasa Inggris (LBI) dalam wadah yang lebih besar yaitu Lembaga Pengembangan Bahasa Asing (LPBA). Lembaga ini dibentuk untuk menampung para santri yang berminat mengembangkan kemampuan lebih dalam dua bahasa tersebut. Sebagai hasilnya, banyak santri binaan lembaga ini yang berhasil meraih juara dalam berbagai kegiatan lomba yang diikuti, baik di dalam mauun di luar pondok. Lulusan LPBA juga banyak yang melanjutkan studinya di pergurauan tinggi ternama baik di dalam maupun di luar negeri.

Kegiatan ekstrakurikuler ini diikuti oleh peserta didik ula, wusthta, dan ulya. akan tetapi untuk tingkatan ulya tidak berkewajiban mengikuti kegiatan, hanya saja sekedar membantu anggota NATO (Nahdlatuth Thalabah) untuk mengawasi dan mengatur berjalannya kegiatan. Karena

1 Moh. Ainin. Metodologi Penelitian Bahasa Arab, (Malang: CV. Bintang Sejahtera, 2016), p. 121. 
peserta didik tingkatan ulya hanya difokuskan untuk KBM (kegiatan belajar mengajar) dan TA (tugas akhir). Bentuk kegiatan ekstrakurikuler sesuai dengan tujuannya meningkatkan kemampuan peserta didik dalam mencapai target capaian beberapa skill kebahasaan, maka pola dan bentuk kegiatan dibagi pada dua bagian sesuai dengan tujuan arah pengembanngan dan hasil out put yang diharapakan.

Jenis kegiatan ekstrakurikuler bahasa Arab di LPBA Nurul Jadid yang didapatkan peneliti dari sumber data (peserta didik ula dan wustha) di antaranya: 1) menyimak (istima'), 2) pidato (khitobah), 3) debat (mujadalah), 4) diskusi (munaqosyah), 5) percakapan (muhawarah), 6) cerdas cermat (tsaqafiyah), 7) bercerita (taqdimul qissoh), 8) membaca berita (qiro'atul anba'), 9) mengarang (insya'), 10) terjemahan (tarjamah), 11) berkreasi (ibtikariyah), dan 12) training MC (raisatul jalsah).

Bahasa Arab dalam kajian sejarah termasuk rumpun bahasa Semit yaitu rumpun rumpun bahasa yang dipakai bangsa-bangsa yang tinggal di sekitar sungai Tigris dan Furat, dataran Syria dan Jazirah Arabia (Timur Tengah). ${ }^{2}$ Dengan demikian pembelajaran bahasa Arab dapat didefinisikan suatu rangkaian kegiatan atau peristiwa yang dilaksanakan terstruktur dan terencana sebagai sarana belajar bahasa Arab guna memperoleh tujuan yang diharapkan.

Kegiatan di LPBA Nurul Jadid ini dilakukan secara sistematis (tahap demi tahap) dan sistemik (menyeluruh) selama satu minggu penuh dan didesain dengan tujuan untuk memfasilitasi peserta didik mencapai kompetensi berupa keterampilan bahasa arab yang diharapkan yang meliputi 1) keterampilan menyimak (maharah istima'), 2) keterampilan berbicara (maharah kalam), 3) keterampilan membaca

2 Azhar Arsyad, .. Bahasa Arab dan Metode Pengajarannya, (Surabaya: Pustaka Pelajar, 2003), p. 25. 
(maharah qira'ah), dan 4) keterampilan menulis (maharah kitabah). ${ }^{3}$

\section{Perencanaan Kegiatan}

1. Organisani Peserta Didik

Pondok Pesantren Nurul Jadid mempunyai beberapa lembaga pengembangan salah satunya adalah lembaga pengembangan bahasa Asing (LPBA). Lembaga ini memiliki 3 badan organisasi, federasi bahasa internasional (FBI) yaitu suatu organisasi khusus untuk peserta didik putra, nahdlatut thalabah (NATO) yaitu, organisasi yang merupakan wadah bagi peserta didik putri untuk mengembangkan kemampuan manajemen dan leadership, dan badan penerbitan majalah Asing (BPMA) yaitu, suatu organisasi yang merupakan wadah bagi peserta didik putra dan putri untuk mengembangkan kemampuan tulis-menulis.

2. Kurikulum

Dalam kegiatan ini juga terdapat kurikulum diantaranya, (1) melalui tatap muka yang terikat dengan struktural program kurikulum, (2) kegiatan kurikuler melalui praktik langsung, untuk memperdalam materi yang ditetapkan sehingga sampai pada target yang direncanakan dengan memuaskan, dan (3) kegiatan ekstrakurikuler (kegiatan mandiri) untuk memperluas, memperkaya wawasan, dan mempraktikkan materi yang telah dipelajari melalui formulasi beragam jenis dan bentuk kegiatan serta mengembangkan kemampuan keterampilan bahasa (life Skill).

3. Susunan jadwal

Hampir semua skenario dari semua kegiatan tersebut sama, mulai dari kegiatan awal hingga kegiatan penutup.

3 Afisah Rosyidah, Pembelajaran Bahasa Arab Dengan Metode Mind Map Untuk Meningkatkan Hasil Belajar Siswa Kelas V Madrasah Ibtidaiyah (Studi Multi Situs Di Min Kanigoro Kras Kediri Dan Mi Tarbiyatul Islam Jemekan Ringinrejo. Thesis. 2015 
Ni'mah Ziyadatul Khusnah, Kholisin, Ahmad Munjin Nasih

Peneliti juga mendapatkan data berupa dokumen jadwal kegiatan ekstrakurikuler bahasa Arab di LPBA Nurul Jadid sebagaimana tabel berikut,

Tabel 4.1 Jadwal Kegiatan Ekstrakurikuler di LPBA Nurul Jadid

\begin{tabular}{|c|c|c|c|}
\hline البرامج & اليوم و الوقت & & الرقم \\
\hline المجادلة & $08.00-10.00$ & \multirow[b]{3}{*}{ الجمعة } & \multirow[b]{3}{*}{1} \\
\hline الاستماع & $11.00-12.00$ & & \\
\hline الخطابة & $13.00-15.00$ & & \\
\hline الإنشاء/الترجمة & $21.00-23.00$ & & \\
\hline القصية & $21.00-23.00$ & السبت & r \\
\hline الخطابة & $21.00-23.00$ & اللأحد & $r$ \\
\hline الثقافية & $21.00-23.00$ & الإثنين & $\varepsilon$ \\
\hline قرآة الأخبار & $21.00-23.00$ & الثاثاء & 。 \\
\hline المناقشة & $21.00-23.00$ & الأربعة & 7 \\
\hline الإنشاء/الترجمة & \multirow{3}{*}{$21.00-23.00$} & & \multirow{3}{*}{ v } \\
\hline رئيسة الجلسـة & & سلمي & \\
\hline الابتكاريية & & & \\
\hline
\end{tabular}

\section{Tema kegiatan}

Selain itu, terdapat tema yang sudah ditentukan oleh NATO di setiap kegiatan ekstrakulikuler. Beberapa kegiatan memiliki tema yang sama, namun dikembangkan oleh peserta didik dengan judul yang berbeda di antaranya pada kegiatan pidato, diskusi, percakapan, terjemahan, dan mengarang yang bertema tentang pendidikan, agama, budaya, dan teknologi.

5. Peraturan dan Tata Tertib Kegiatan

Lembaga ini mempunyai peraturan dan tata tertib kegiatan secara umum di antaranya, (1) semua peserta didik 
wajib berbahasa Arab di manapun berada, (2) dilarang mendengarkan musik atau lagu Indonesia dengan keras, jika melanggar maka dikenai sanksi berupa berdiri, MP3 dirampas dan mencari lalu menghafal lima belas mufrodat asing, (3) dilarang kerasan di gang lain pada jam 24.00, jika melanggar maka dikenai sanksi berupa membuat insya' satu setengah kertas folio, mencari dua puluh mufrodat asing dan menghafalnya, (4) dilarang menerima tamu di dalam kamar, jika melanggar maka dikenai sanksi berupa menghafalkan qowaid, dan menghafal lima belas mufrodat asing, (5) dilarang memakai embel-embel seperti: duh, kah, anu dan lainnya, jika melanggar maka dikenai sanksi berupa menghafal sebanyak tiga mufrodat untuk ula dan lima untuk wustha lalu ditashrifkan, dan (6) bagi yang tidak berbahasa akan dikenai dua point, jika melanggar maka dikenai sanksi berupa menghafal sebanyak tiga mufrodat untuk ula dan lima untuk wustha serta mentasrifnya, lalu mengarang satu setengah halaman untuk ula dan dua halaman untuk wustha.

Perencanaan pembelajaran merupakan hal yang penting dalam sebuah sistem pembelajaran, dengan perencanaan yang baik diharapkan tujuan yang diharapkan dapat tercapai. salah satu upaya untuk membelajarkan peserta didik yaitu dengan perencanaan pembelajaran. Dalam proses pembelajaran terdapat beberapa kegiatan antara lain memilih, menetapkan, mengembangkan metode guna mencapai tujuan yang di inginkan dan kegiatan tersebut merupakan inti dari perencanaan pembelajaran. ${ }^{4}$

Lembaga pengembangan bahasa Asing (LPBA) mempunyai tiga organisasi yaitu federasi bahasa internasional (FBI), nahdlatut thalabah (NATO), dan badan penerbitan majalah Asing (BPMA). Dan sistem perencanaan lainnya yang

${ }^{4}$ Hamzah B. Uno, Perencanaan Pembelajaran, (Jakarta: Bumi Aksara, 2011), p. 2. 
terdapat di lembaga ini diantaranya, kurikulum, susunan jadwal, tema kegiatan, peraturan dan tata tertib.

\section{Pelakasanaan Kegiatan}

Berdasarkan hasil observasi yang dilakukan oleh peneliti terhadap kegiatan-kegiatan eksrakurikuler mulai dari kegiatan awal hingga kegiatan penutup, maka diperoleh data sebagai berikut, kegiatan yang diikuti oleh peserta didik tingkatan ula dan wushta khususnya wilayah Az-Zainiyah AlBayan dilaksanakan setiap malam hari setelah kegiatan belajar mengajar (KBM) berlangsung dan hari Jum'at mulai pagi sampai malam selama kurang lebih satu jam. Kegiatan dilaksanakan di depan asrama dan di gedung SMP. Pelaksanaan kegiatan bahasa Arab selalu didampingi oleh pengurus dalam bentuk pengawasan maupun komunikasi secara langsung terhadap individu maupun kelompok sekaligus sebagai pentashih diakhir kegiatan.

Hasil wawancara dalam pelaksanaan kegiatan ekstrakurikuler ini adalah Masing-masing kegiatan terdapat sanksi bagi peserta didik yang melanggar peraturan, tidak lancar pada saat tampil di depan, dan tidak mengikuti kegiatan. Sanksinya yaitu, penyetoran mufrodat, berdiri, menghafal qowaid, dan tashrif. Peserta didik yang mendapat sanksi, maka akan berdiri selama kegiatan berlangsung. Jika kegiatan selesai maka sanksi akan dilanjutkan setelah kegiatan dengan duduk sambil menghafal lalu disetorkan ke NATO.

Untuk kelebihannya, peserta didik LPBA sering mendapatkan penghargaan dari lomba-lomba yang diikuti oleh peserta didik yang dilaksanakan di dalam maupun di luar pondok pesantren, diantaranya pada maharah kalam di bidang lomba debat selama empat tahun berturut-turut. Selain itu, tidak cukup hanya dengan hasil prestasi yang telah dicapai untuk mengukur kemampuan peserta didik namun 
bentuk kreatifitas peserta didik dalam berbahasa Arab juga mengalami perkembangan yang diperoleh dari kesehariannya dan partisipasi dalam mengikuti kegiatan. Dan kekurangannya dari kegiatan tersebut adalah peserta didik masih sering berbicara bahasa Arab menggunakan logat madura, karena pada dasarnya mayoritas berasal dari lingkungan Madura. Jadi hal itu, sangatlah berpengaruh terhadap pelaksanaan kegiatan-kegiatan ekstrakurikuler.

Pelaksanakan pembelajaran bahasa arab di LPBA Nurul Jadid berawal dari rapat penyusunan jadwal kegiatan yang kemudian menjadi sebuah agenda kegiatan yang dilaksanakan setiap harinya oleh peserta didik. Dalam pelaksanaannya, LPBA Nurul Jadid menjadikan semua kegiatan ekstrakurikuler bahasa arab yang dilaksanakan menjadi sebuah kesatuan sistem pembelajaran yang didalamnya terdapat kegiatankegiatan yang saling terkait dan saling mempengaruhi satu dengan yang lainnya. Kualitas sistem dipengaruhi oleh kualitas unsur-unsurnya, jika salah satu unsur tidak dapat berjalan beriringan dengan unsur yang lainnya, maka efektifitas sistem menjadi terganggu. ${ }^{5}$

Lingkungan yang kondusif juga merupakan faktor pendukung dan juga berpengaruh terhadap proses pembelajaran bahasa arab yang berlangsung. Lingkungan belajar adalah kondisi dan segala fasilitas yang digunakan untuk kegiatan belajar sehari-hari ${ }^{6}$. Menyadari hal tersebut, lingkungan di asrama LPBA Nurul Jadid mewajibkan peserta didik untuk menggunakan bahasa arab dalam kesehariannya baik berkomunikasi maupun yang lainnya sehingga peserta didik terlibat secara aktif.

5 Oemar Hamalik, Proses Belajar Mengajar. (Jakarta: PT. Bumi Aksara, 2003), p. 102.

${ }^{6}$ Bambang Budi Wiyono, Hubungan antara lingkungan belajar,(Jakarta: Forum penelitian, 2003), p. 29. 
Fasilitas yang disediakan juga bermacam-macam. Menurut terdapat tiga hal fasilitas sebagai unsur penunjang belajar yakni media atau alat bantu belajar, peralatanperlengkapan belajar, dan ruangan belajar. Adapun fasilitas yang terdapat di LBPA Nurul Jadid antara lain: (1) LCD Proyektor, (2) laptop, (3) sound system, (4) mikrofon, dan (5) papan tulis. Fasilitas-fasilitas tersebut digunakan untuk lebih memudahkan peserta didik memahami materi dalam proses pembelajaran.

\section{Evaluasi Kegiatan}

Berdasarkan pengisian angket yang dilakukan oleh pengurus, bahwa kegiatan evaluasi ini dilaksanakan dalam satu bulan sekali, yang bertempat di kelas SMP Nurul Jadid bersama dengan rekan-rekan pengurus putra-putri beserta direktur LPBA Nurul Jadid. Hasil wawancara dengan pengurus pada tanggal 3 mei 2019 didapatkan bahwa bentuk evaluasi kegiatan dilaksanakan dalam satu bulan sekali. Narasumber mengatakan bahwa bentuk evaluasi kegiatan ekstrakulikuler adalah sistem laporan perdivisi. Perdivisi harus melaporkan tentang kegiatan yang sudah berjalan, baik dari segi kendala, maupun dari kegiatan yang kurang efisien juga disampaikan. Jika ada permasalahan, maka akan ada solusi terbaik untuk masalah tersebut. Terdapat tiga divisi dalam kegiatan estrakulikuler tersebut, yaitu divisi kebahasaan, divisi pendidikan, dan divisi kesenian.

Evaluasi kegiatan ini dilaksanakan secara menyeluruh. Dengan adanya laporan per divisi maka akan mempermudah pengurus (ustadz dan ustadzah) dalam memberikan solusi di setiap permasalahan yang dialami oleh peserta didik. Kegiatan tersebut dilihat dari efektif dan keefesiennya, jika dirasa tidak mencukupi maka akan diganti bentuk modifikasi kegiatannya. Untuk penilaiannya melalui kemampuan peserta didik dalam 
mengikuti kegiatan ekstrakurikuler, jika peserta didik mampu dan menguasai maka akan dikasih reward perkegiatannya.

Evaluasi bertujuan untuk melihat atau mengukur belajar peserta didik dalam hal penguasaan materi yang telah dipelajari sesuai dengan tujuan-tujuan yang telah ditetapkan. ${ }^{7}$ Kegiatan evaluasi di LPBA Nurul Jadid dilaksanakan satu bulan sekali dengan bentuk laporan dari masing-masing divisi antara lain: 1) divisi kebahasaan meliputi; kegiatan mengarang, terjemahan, percakapan dan cerdas cermat; 2) divisi pendidikan meliputi; pidato, debat, dan diskusi; 3) divisi kesenian meliputi membaca berita dan bercerita. Evaluasi ini dilakukan bertujuan untuk mengetahui dan menyelesaikan kendala-kendala yang terjadi dalam proses pelaksanaan semua kegiatan ekstrakurikuler bahasa arab.

\section{Kesimpulan}

Bentuk kegiatan ekstrakurikuler untuk meningkatkan kemampuan peserta didik dalam mencapai target capaian beberapa skill kebahasaan yang sesuai dengan tujuan arah pengembanngan dan hasil out put yang diharapakan. Jenis kegiatan ekstrakurikuler bahasa Arab di LPBA Nurul Jadid yang didapatkan peneliti dari sumber data (peserta didik ula dan wustho) di antaranya: 1) menyimak (istima'), 2) pidato (khitobah), 3) debat (mujadalah), 4) diskusi (munaqosyah), 5) percakapan (muhawarah), 6) cerdas cermat (tsaqafiyah), 7) bercerita (taqdimul qissoh), 8) membaca berita (qiro'atul anba'), 9) mengarang (insya'), 10) terjemahan (tarjamah), 11) berkreasi (ibtikariyah), dan 12) training MC (raisatul jalsah).

Kegiatan ini dilaksanakan setiap malam hari setelah kegiatan belajar mengajar (KBM) berlangsung dan hari Jumat mulai pagi sampai malam. Kegiatan dilaksanakan di depan

7 Nana Sudjana, Penilaian Hasil Proses Belajar Mengajar. Cetakan ketujuh. (Bandung: PT Remaja Rosdakarya, Cet.7, 2003), p.148. 
asrama dan di aula SMP. Semua kegiatan akan diawasi oleh pengurus inti yang juga sebagai pentashih di akhir kegiatan. Kegiatan evaluasi di LPBA Nurul Jadid dilaksanakan dalam satu bulan sekali, yang bertempat di kelas SMP Nurul Jadid bersama dengan rekan-rekan pengurus putra-putri beserta direktur LPBA Nurul Jadid. Gunanya evaluasi tersebut untuk memecahkan masalah peserta didik dalam kegiatannya dan memberikan solusinya.

\section{Daftar Rujukan}

Ainin, Moh. 2016. Metodologi Penelitian Bahasa Arab. Malang: CV. Bintang Sejahtera

Arsyad, Azhar. 2003. Bahasa Arab dan Metode Pengajarannya. Surabaya: Pustaka Pelajar

Hamalik, Oemar. 2002. Psikologi Belajar Mengajar. Bandung: Sinar Baru Algensido

Hamalik, Oemar. 2003. Proses Belajar Mengajar. Jakarta: PT. Bumi Aksara

Rosyidah, Afisah. 2015. Pembelajaran Bahasa Arab Dengan Metode Mind Map Untuk Meningkatkan Hasil Belajar Siswa Kelas V Madrasah Ibtidaiyah (Studi Multi Situs Di Min Kanigoro Kras Kediri Dan Mi Tarbiyatul Islam Jemekan Ringinrejo. Thesis.

http://repo.iain-tulungagung.ac.id/id/eprint/3217. Diakses pada: 9 Juli 2019

Sudjana, Nana. 2003. Penilaian Hasil Proses Belajar Mengajar. Cetakan ketujuh. Bandung: PT Remaja Rosdakarya

Uno, Hamzah B. 2011. Perencanaan Pembelajaran. Jakarta: Bumi Aksara

Wiyono, Bambang Budi. 2003. Hubungan antara lingkungan belajar. Jakarta: Forum penelitian 